\title{
Determination of Generator Steady State Stability Limit for Multimachine System based on Network Losses Concept
}

\author{
Rusilawati $^{1,2,}$, Irrine Budi Sulistiawati ${ }^{3}$, Adi Soeprijanto ${ }^{1}$, and Rony Seto Wibowo ${ }^{1}$ \\ ${ }^{1}$ Department of Electrical Engineering, Institut Teknologi Sepuluh Nopember, Gedung B, C \& AJ \\ Kampus ITS Sukolilo, Surabaya 60111, Indonesia \\ ${ }^{2}$ Department of Electrical Engineering, Akademi Teknik Pembangunan Nasional, Grand Palace \\ Park Jl. A.Yani km 32, Loktabat Banjarbaru 70714, Indonesia \\ ${ }^{3}$ Department of Electrical Engineering, Institut Teknologi Nasional, Jl. Raya Karanglo km 2, \\ Malang 65145, Indonesia
}

\begin{abstract}
In the multimachine circumstances, it is difficult to analyze the steady state stability of each generator. In previous research, analysis of the steady state stability limit has been carried out but only look at the stability of the overall system. Therefore, to analyze the stability of each generator, the multimachine system must be changed into a Single Machine to Infinite Bus (SMIB) system by collecting all the loads into one central load in the infinite bus. The method to change from the multimachine system to SMIB system is presented in this paper. The multimachine system is converted into an equivalent impedance (req and xeq) and an equivalent load based on losses concept. After req and xeq is calculated, then by using steady state stability limit concept, the value of the maximum generation of each generator units can be determined. By means of maximum generation is the maximum output power limit that can be generated without causing unstability. ETAP simulation is used to validate the calculation results of the proposed method. The method was applied to units generator in Java Bali system $500 \mathrm{kV}$.
\end{abstract}

Key words: Equivalent reactance, equivalent resistance, generator steady state stability limit, maximum generation, the losses concept

\section{Introduction}

The power balance between the load and the generator output power is one measure of the power system operation stability. In power system operation, load always changes in the capacity and location at any time, and this mean that the system requires each plant to adjust the output power through the control of the governor and excitation to follow the changes in the system load. If this is not done, it will decrease the power balance and the efficiency of the system causing the system performance deteriorated.

* Corresponding author: habsyi.sila@yahoo.com 
Electric power system generally consists of generating units connected to the network to serve the load. Electric power systems that have a lot of machines are usually distribute power to the load through the interconnected system. The main purpose of the interconnected system is to maintain the continuity and the availability for the increasing of the needs of electric power. The growing of the power system can result the poor performance when the system is disturbed. One effect of the interference on the system is the electromechanical oscillations, if not be attenuated can cause disruption of the system and turn out from the area of stability, resulting a worse effect as the total blackout [1,2].

In recent years, power systems are operated almost at the stability limit due to the use of out of date of the power system infrastructure construction compared to the increase in demand of electric power and the long-distance transmission system. If the load demand beyond the limits of the maximum power (active power and reactive power) that can be generated and transmitted from the source to the load area, and no improvement action is taken, the voltage load area will become unstable and collapse may occur.

Steady-state stability limit of the power system is steady state operating condition in which the power system is still in a stable condition but for a small change of the parameters of the operation will bring the system loses its stability [3]. Initial definition refers to the concept that "the stability of the system to the condition of load changes gradually and slowly change" [4]. Voltage collapse, causing the system to lose synchronism and instability caused by the strengthening of small oscillations of all forms of the steady state instability [5].

Load flow method can be used to determine steady-state stability limit of a power system by increasing the load until the load flow process becomes not convergent. Continuation Power Flow Method (CPF) has also been frequently used to determine the relationship between the loading parameters to voltage at each bus. Both conventional methods have a weakness because they do not incorporate internal reactance generator value in the modelling and analysis. In addition, another weakness is in the computational because the looping iteration process of Load Flow and CPF method require a longer computing time so this method is not suitable to be implemented in the real-time monitoring system. Practical studies to determine the steady state limits have also been developed in Russia to decrease the mathematical equations of the Jacobian Dynamic but this method also requires computation time is much longer [5].

In previous research analysis of the steady-state stability limit has been carried out [57], but still these researches only look at the stability of the overall system, making it difficult to analyze the stability of each bus or generator.

In this paper, the losses concept is used to determine the maximum generation of units generator on each generator bus. Maximum generation of generator is influenced by several factors: source voltage, phase angle and networks impedance value [8]. Equivalent network impedance can be determined by knowing the losses in the network, then the multimachine system can be changed into SMIB system with an equivalent impedance and an equivalent load. Note that the determination of equivalent impedance value using losses concept has used in [8] and [9], but the change from the multimachine system to Single Machine to Infinite Bus (SMIB) system is not provided. Maximum generation of generator is a generator steady state stability limit that can be calculated after the network impedance is obtained.

\section{Concept of single machine steady state stability}

Electric power system is defined as a collection of some of the power stations and substations, which are interconnected by transmitting nets each other. Transmission nets form a unified system known as interconnection system. With the interconnection system, 
the system will be more reliable because of interconnected systems can assist other systems in sending power requirement if one of the systems in plants have a short fall or trip.

Interconnection system in operating system aims to obtain a combination of electric power generation as economical as possible, so achieving a balance between the power available and the power needed. System interconnection between the generators of the power system shown in Figure 1 [10].

To analyze the steady state stability of each generator, the multimachine system must be changed to SMIB system first. The method to change the multimachine system to SMIB system will discuss in section III.

If the system is considered to have no power loss, the power generated equal to the power delivered to the infinite bus. The equation for $\mathrm{P}_{\mathrm{G}}$ written as:

$$
P_{G}=\frac{|E \| V|}{\mathrm{X}_{\mathrm{e}}} \sin \delta
$$

Figure 2 shows a synchronous generator connected to an infinite bus. Bus voltage $|V|$ is the constant magnitude when the net is very large (infinite). Assuming the generator operating at fixed excitation, maintaining fixed $E$ and fixed $\mathrm{X}_{\mathrm{e}}$, then $\mathrm{P}_{\mathrm{G}}$ is a function of the power angle $\delta$. Characteristics power- angle shown in Figure 3. The maximum power is delivered to an infinite bus occurred at $\delta=90^{\circ}$. Equation (1) can be written as:

$$
P_{G}=P=P_{\max }
$$

Stable system occurs in less than $P_{\max }$ value, which occurs at $\delta<90$. This can be explained as follows: suppose that the generator works in steady state conditions and transmit power $\mathrm{P}_{\mathrm{G}}{ }^{0}$ on initial power angle $\delta_{0}$ as shown in the picture angle-power characteristics in point a in Figure 3. At a point turbine output $\mathrm{P}_{\mathrm{T}}{ }^{0}$ equal to the power generated (losses ignored). If there were no changes, the steam valve (throttle valve) which controls the turbine generator is opened slowly. Mechanical power input will be higher than the electrical output power. This power is equal to the difference $\Delta \mathbf{P}_{\mathrm{T}}=\mathrm{P}_{\mathrm{T}}$ $-P_{G}$.

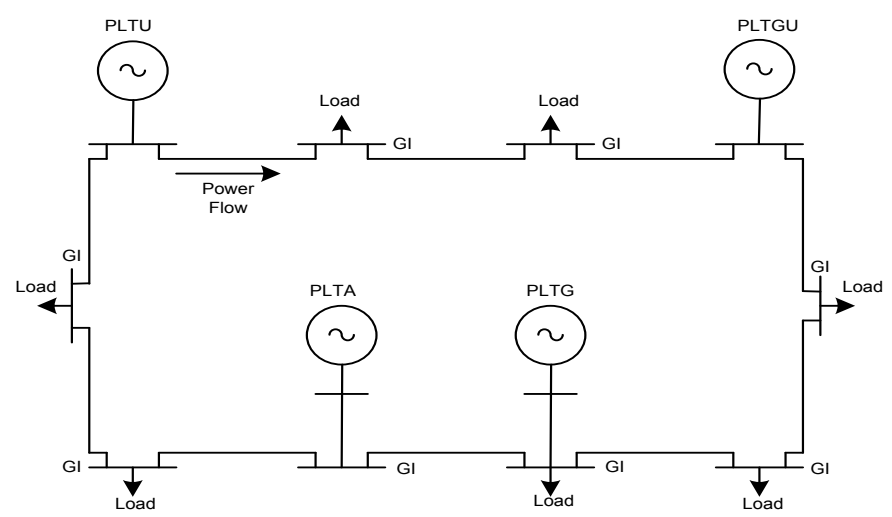

Fig. 1. System interconnection of electric power systems. 


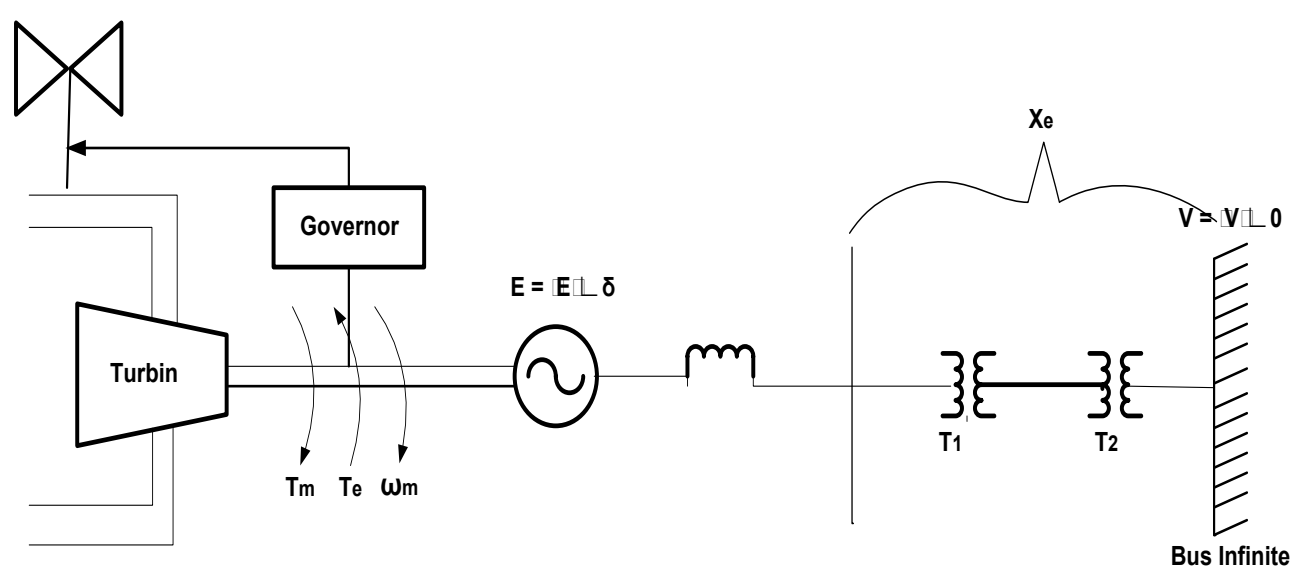

Fig. 2. A machine connected to an infinite bus.

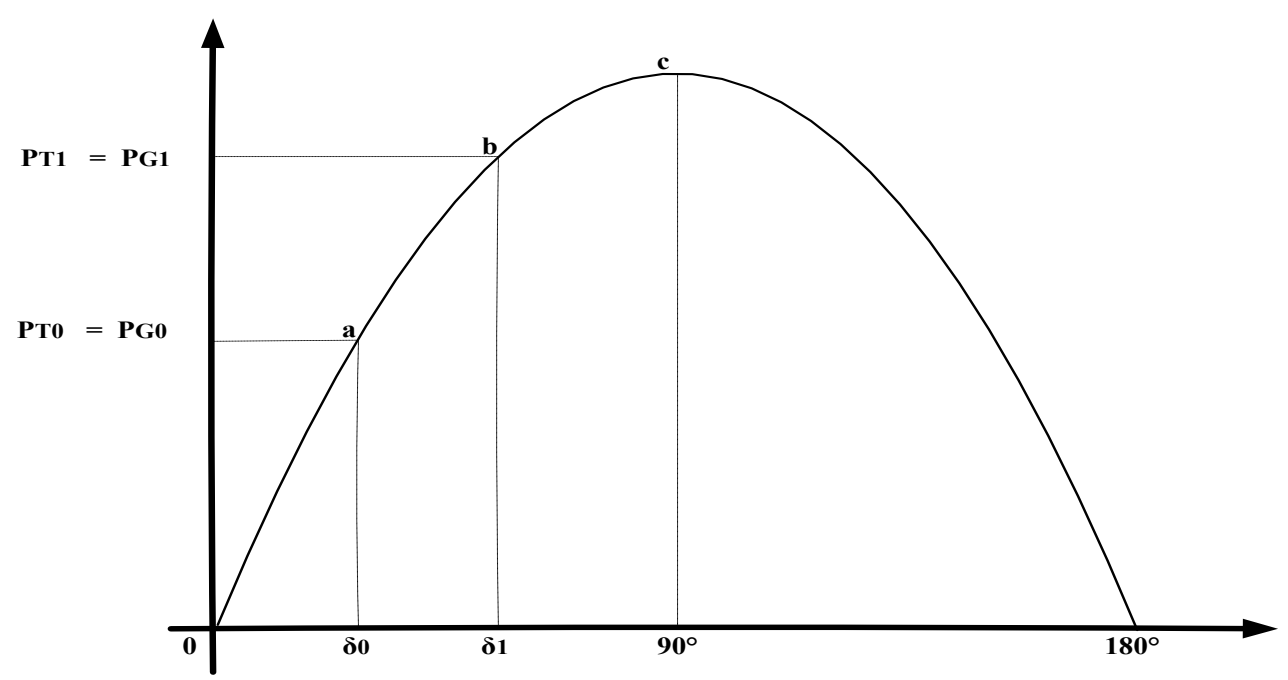

Fig. 3. Characteristics of the real power and the power angle.

Because there is an imbalance of power, then the speed will be slightly up and power angle will also rise. When the power angle $\delta$ rise from $\delta_{0}$, the electric power generator will rise. The increase in power will match with the increase in power output of the turbine. The operating system will be stable with the new power angle $\delta$. Whenever valve steam (water) is opened and steam (water) increases, the output of electric power generators will rise.

Suppose turbine output is increased gradually until the point $\mathrm{c}$ (the characteristic power-angle), then the maximum power will be achieved. If the increase of power turbine continues, then the power angle will rise, while the power received by the infinite bus will drop. So that the difference between the input and output increase and will accelerate the rotation generators greater. 
When the power angle is increased beyond the angle of $90^{\circ}$, the received power will drop rapidly and becomes zero at the angle of $180^{\circ}$. The acceleration of the generator rotor will increase. In other words, if the power angle is increased beyond $90^{\circ}$, the synchronism is lost.

$\mathrm{P}_{\max }$ is the steady-state stability limit of the system which is the maximum power that can be delivered under slow disturbance. If an attempt is made to transmit power over this power limit, the synchronism is lost. The maximum power is also referred to as the pull-out power [6].

$$
P_{\max }=\frac{|E \| V|}{X}
$$

where $\mathrm{X}$ is the reactance transfer between $\mathrm{E}$ and $\mathrm{V}$,

$$
\begin{aligned}
& X=X_{d}{ }^{\prime}+X_{e q} \\
& E=V+j I X
\end{aligned}
$$

where $X_{d}$ ' is generator reactance, $x_{\mathrm{eq}}$ is equivalent reactace, $\mathrm{E}$ is generator terminal voltage, $\mathrm{I}$ is inducted current and $\mathrm{V}$ is generator bus voltage.

It can be concluded that the maximum power that can be transferred by the generator is very dependent on the reactance network. If the generator transfers beyond this maximum power limit, that can be instability as loss of synchronization on the generator. If the load still increases, the stator and rotor magnetic coupling will be loose.

\section{Reduction of the multimachine system to SMIB system using losses concept}

Electric power system is a large system with multi generators (multimachine). If the generator stability analysis should be carry out in multimachine system, it will be very difficult. Therefore, the multimachine system as shown in Figure 4 must be changed to a Single Machine to Infinite Bus (SMIB) system first.

The procedure to change the multimachine system to SMIB system and the maximum generation calculation procedure $\left(\mathrm{P}_{\max }\right)$ of each generator unit can be explained as follows:

i. Prepare the power system data. Run the load flow with all generators are off except the observed generator (the one that stability will be analyzed and which the equivalent impedance will be calculated).

ii. Calculate the current value I of the observed generator using the following equation:

$$
I *=\left(\frac{S_{i n}}{\sqrt{3 x} V_{i}}\right)
$$

where: $S_{\text {in }}=$ generated complex power of generator

$\mathrm{Vi}=$ voltage of bus I

$\mathrm{S}_{\mathrm{L}}=\mathrm{P}_{\mathrm{L}}+\mathrm{j} \mathrm{Q}_{\mathrm{L}}$ with $\mathrm{S}_{\mathrm{L}}, \mathrm{P}_{\mathrm{L}}$ and $\mathrm{Q}_{\mathrm{L}}$ are complex power losses, active power losses and reactive power losses between two bus, respectively.

iii. Equivalent current is equal with the observed generator current.

iv. Calculate the equivalent value of $r_{e q}$ and $x_{e q}$ using the following equations:

$$
\begin{gathered}
Z_{e q}=\frac{S_{L}}{I^{2}}=\frac{P_{L}+j Q_{L}}{I^{2}} \\
r_{e q}=Z_{e q} \cos \theta
\end{gathered}
$$

and 


$$
x_{e q}=Z_{e q} \sin \theta
$$

v. Calculate E using Equation 5.

vi. Determine the maximum generation of observed generator which is the generator steady-state stability limit using Equation 3.

vii. Repeat this procedure for all generators.

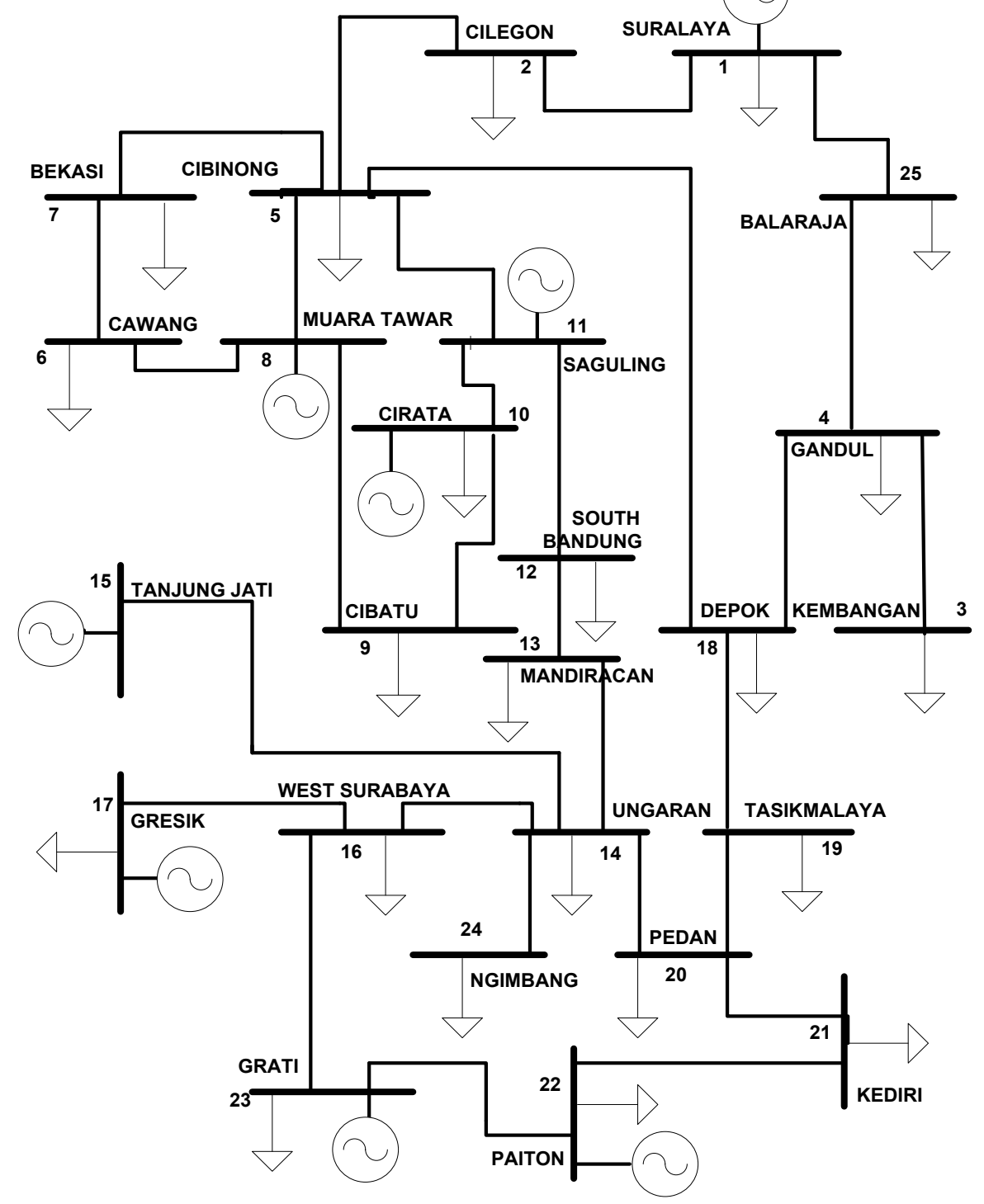

Fig. 4. Java-Bali multimachine system $500 \mathrm{kV}$. 


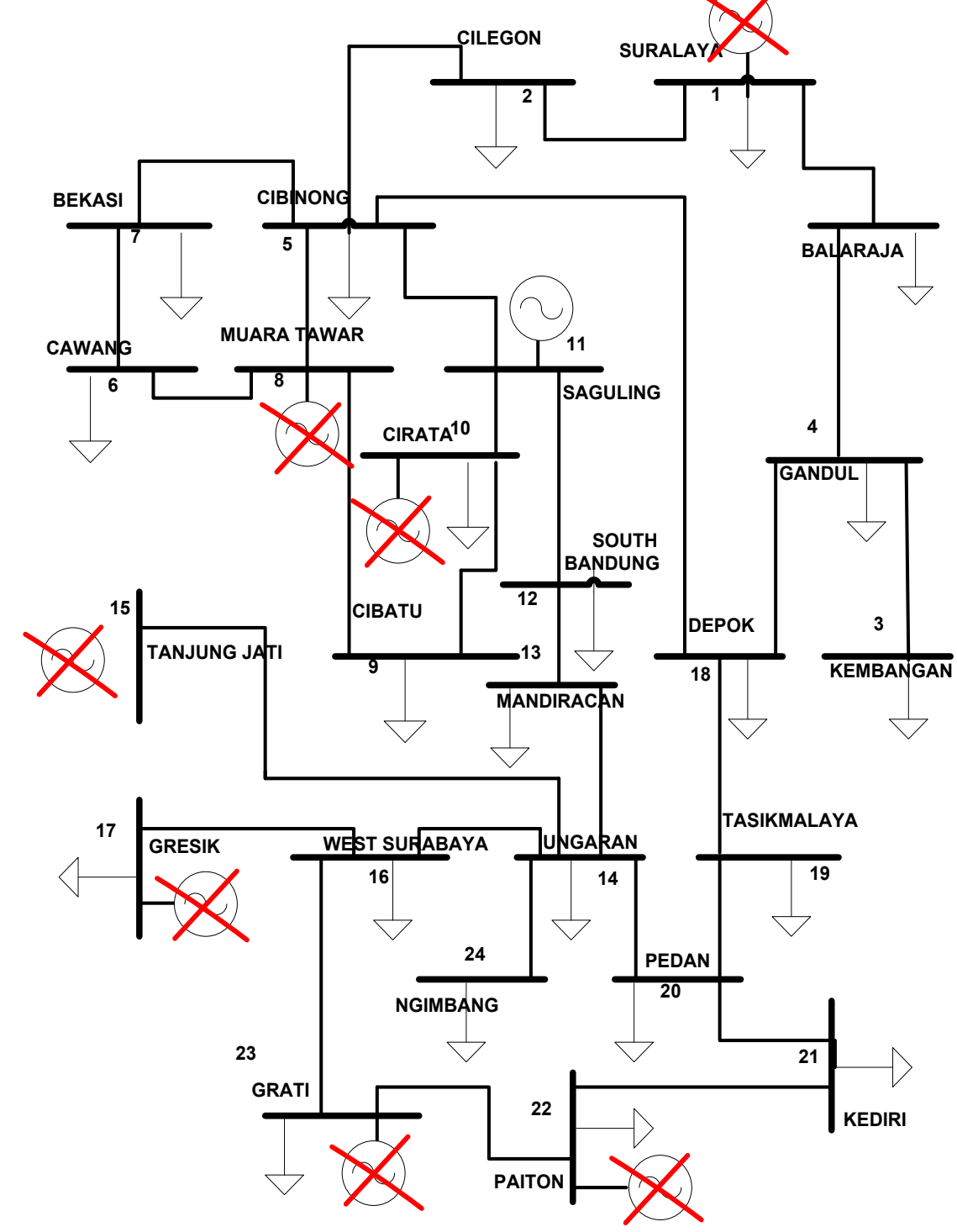

Fig. 5. The procedure to change the multimachine system to SMIB system.

Figure 5 shows the procedure to change the multimachine system to SMIB system. The multimachine system is converted into an equivalent impedance and an equivalent load as shown in Figure 6.

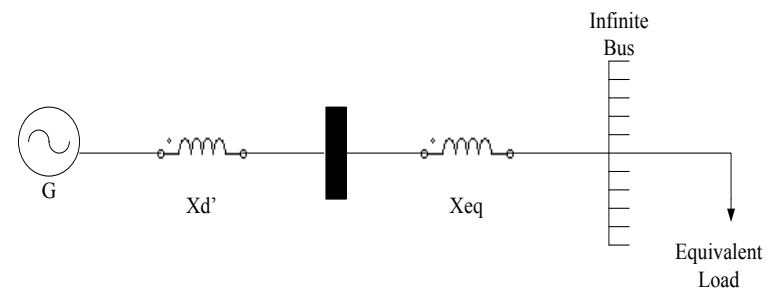

Fig. 6. Single machine to infinite bus (SMIB) system. 


\section{Simulation and results}

The simulation using the $500 \mathrm{kV}$ transmission system of Java-Bali that consisting of one swing bus, seven generator bus and 17 load bus. Figure 4 shows a picture of SLD (Single Line Diagram) of Java-Bali system $500 \mathrm{kV}$.

There are eight generators in the Java-Bali system $500 \mathrm{kV}$. The generator is connected to the load bus through the lines with the different conductor type. The Java-Bali system $500 \mathrm{kV}$ data is contained in Table 1, Table 2, and Table 3.

Table 1. Transmission system data of Java-Bali $500 \mathrm{kV}$.

\begin{tabular}{|c|c|c|c|c|}
\hline $\begin{array}{l}\mathrm{i} \\
-\end{array}$ & R (p.u) & $X(p . u)$ & $1 / 2$ B (p.u) & Tap Setting \\
\hline 12 & 0.000626496 & 0.007008768 & 0 & 1 \\
\hline 124 & 0.003677677 & 0.035333317 & 0 & 1 \\
\hline 25 & 0.013133324 & 0.146925792 & 0.003530571 & 1 \\
\hline 34 & 0.001513179 & 0.016928308 & 0 & 1 \\
\hline $4 \quad 18$ & 0.000694176 & 0.006669298 & 0 & 1 \\
\hline 57 & 0.004441880 & 0.042675400 & 0 & 1 \\
\hline 58 & 0.006211600 & 0.059678000 & 0 & 1 \\
\hline 511 & 0.004111380 & 0.045995040 & 0.004420973 & 1 \\
\hline 67 & 0.001973648 & 0.018961840 & 0 & 1 \\
\hline 68 & 0.005625600 & 0.054048000 & 0 & 1 \\
\hline 89 & 0.002822059 & 0.027112954 & 0 & 1 \\
\hline 910 & 0.002739960 & 0.026324191 & 0 & 1 \\
\hline 1011 & 0.001474728 & 0.014168458 & 0 & 1 \\
\hline 1112 & 0.001957800 & 0.021902400 & 0 & 1 \\
\hline 1213 & 0.006990980 & 0.067165900 & 0.006429135 & 1 \\
\hline 1314 & 0.013478000 & 0.129490000 & 0.012394812 & 1 \\
\hline 1415 & 0.013533920 & 0.151407360 & 0.003638261 & 1 \\
\hline 1416 & 0.015798560 & 0.15178480 & 0.003632219 & 1 \\
\hline 1420 & 0.009036120 & 0.086814600 & 0 & 1 \\
\hline 1617 & 0.001394680 & 0.013399400 & 0 & 1 \\
\hline 1623 & 0.003986382 & 0.044596656 & 0 & 1 \\
\hline 185 & 0.000818994 & 0.007868488 & 0 & 1 \\
\hline $18 \quad 19$ & 0.014056000 & 0.15724800 & 0.015114437 & 1 \\
\hline $19 \quad 20$ & 0.015311000 & 0.171288000 & 0.016463941 & 1 \\
\hline $20 \quad 21$ & 0.010291000 & 0.115128000 & 0.011065927 & 1 \\
\hline 2122 & 0.010291000 & 0.115128000 & 0.011065927 & 1 \\
\hline $22 \quad 23$ & 0.004435823 & 0.049624661 & 0.004769846 & 1 \\
\hline $24 \quad 4$ & 0.002979224 & 0.028622920 & 0 & 1 \\
\hline $25 \quad 14$ & 0.023479613 & 0.225580588 & 0.100970352 & 1 \\
\hline 2516 & 0.005966652 & 0.057324466 & 0 & 1 \\
\hline
\end{tabular}


Table 2. Generation system data of Java-Bali $500 \mathrm{kV}$.

\begin{tabular}{|c|l|c|c|c|c|}
\hline \multirow{2}{*}{$\begin{array}{c}\text { Bus } \\
\text { No }\end{array}$} & \multirow{2}{*}{ Generator } & \multicolumn{2}{|c|}{ Active Power (MW) } & \multicolumn{2}{c|}{$\begin{array}{c}\text { ReactivePower } \\
\text { (MVAR) }\end{array}$} \\
\cline { 3 - 6 } & & Minimum & Maximum & Minimum & Maximum \\
\hline 1 & Suralaya & 1500 & 3803 & -600 & 2040 \\
\hline 8 & Muaratawar & 1040 & 2096 & -700 & 1540 \\
\hline 10 & Cirata & 400 & 948 & -488 & 488 \\
\hline 11 & Saguling & 400 & 700 & -140 & 440 \\
\hline 15 & Tanjung Jati & 600 & 2808 & -240 & 720 \\
\hline 17 & Gresik & 238 & 828 & -610 & 660 \\
\hline 22 & Paiton & 1425 & 4710 & -840 & 1920 \\
\hline 23 & Grati & 150 & 850 & -302 & 566 \\
\hline
\end{tabular}

Table 3. Generator reactance data of Java-Bali $500 \mathrm{kV}$.

\begin{tabular}{|c|l|c|c|}
\hline $\begin{array}{c}\text { Bus } \\
\text { No }\end{array}$ & \multicolumn{1}{|c|}{ Generator } & Ra & Xd' \\
\hline 1 & Suralaya & 0 & 0.1418445 \\
\hline 8 & Muara Tawar & 0 & 0.0498565 \\
\hline 10 & Cirata & 0 & 0.0982143 \\
\hline 11 & Saguling & 0 & 0.2820233 \\
\hline 15 & Tanjung Jati & 0 & 0.4842950 \\
\hline 17 & Gresik & 0 & 0.1869112 \\
\hline 22 & Paiton & 0 & 0.1567810 \\
\hline 23 & Grati & 0 & 0.2630799 \\
\hline
\end{tabular}

The simulations is performed with the load is $11278 \mathrm{MW}$. Data loading is presented in Table 4.

The simulation steps in finding the steady state stability limit $\left(\mathrm{P}_{\max }\right)$ for each generator are as follows:

i. The generator on bus 11 is used as observed generator. The load flow result with all generators are off except the observed generator on bus 11 is presented in Table 5.

ii. From Table 5, we can see that the generated power of generator is $536.027 \mathrm{MW}$ and 211.426 MVar. Voltage of bus 11 is $1.00 \mathrm{pu}$. The active power losses is 1.027 MW and the reactive power losses is -220.448 MVar.

iii. Calculation result for the current value I of the observed generator using Equation 6 is $665.358 \mathrm{~A}$.

iv. The $r_{\text {eq }}$ value and the $x_{\text {eq }}$ value can calculate using Equation 7, Equation 8 and Equation 9, and we get 0.0000092792-j 0.00199184.

v. We can determine the maximum generation of observed generator which is the generator steady-state stability limit using (3), and be obtained $668.929 \mathrm{MW}$

vi. Repeat this procedure for all generators. The calculation results of $r_{e q}$ and $x_{e q}$ value using the losses concept as described in section III can be seen in Table 6 . 
Table 4. Transmission system bus data of Java-Bali 500kV.

\begin{tabular}{|c|c|c|c|c|c|c|}
\hline \multirow{2}{*}{$\begin{array}{l}\text { Bus } \\
\text { No }\end{array}$} & \multirow{2}{*}{ Bus Name } & \multirow{2}{*}{ Bus Type } & \multicolumn{2}{|l|}{ Voltage } & \multicolumn{2}{|c|}{ Load } \\
\hline & & & Magnitude & Angle & MW & MVAR \\
\hline 1 & Suralaya & Slack & 1.02 & 0 & 153 & 45 \\
\hline 2 & Cilegon & Load & 1 & 0 & 703 & 227 \\
\hline 3 & Kembangan & Load & 1 & 0 & 760 & 261 \\
\hline 4 & Gandul & Load & 1 & 0 & 544 & 181 \\
\hline 5 & Cibinong & Load & 1 & 0 & 697 & 215 \\
\hline 6 & Cawang & Load & 1 & 0 & 760 & 181 \\
\hline 7 & Bekasi & Load & 1 & 0 & 646 & 170 \\
\hline 8 & Muaratawar & Generator & 1 & 0 & 0 & 0 \\
\hline 9 & Cibatu & Load & 1 & 0 & 823 & 317 \\
\hline 10 & Cirata & Generator & 1 & 0 & 680 & 245 \\
\hline 11 & Saguling & Generator & 1 & 0 & 0 & 0 \\
\hline 12 & South Bandung & Load & 1 & 0 & 590 & 351 \\
\hline 13 & Mandiracan & Load & 1 & 0 & 397 & 136 \\
\hline 14 & Ungaran & Load & 1 & 0 & 392 & 363 \\
\hline 15 & Tanjung Jati & Generator & 1 & 0 & 0 & 0 \\
\hline 16 & WestSurabaya & Load & 1 & 0 & 862 & 317 \\
\hline 17 & Gresik & Generator & 1 & 0 & 210 & 91 \\
\hline 18 & Depok & Load & 1 & 0 & 0 & 0 \\
\hline 19 & Tasikmalaya & Load & 1 & 0 & 277 & 17 \\
\hline 20 & Pedan & Load & 1 & 0 & 524 & 244 \\
\hline 21 & Kediri & Load & 1 & 0 & 358 & 206 \\
\hline 22 & Paiton & Generator & 1 & 0 & 839 & 272 \\
\hline 23 & Grati & Generator & 1 & 0 & 130 & 193 \\
\hline 24 & Ngimbang & Load & 1 & 0 & 732 & 287 \\
\hline 25 & Balaraja & Load & 1 & 0 & 264 & 58 \\
\hline & & & & & 11278 & 4377 \\
\hline
\end{tabular}

Load flow analysis in ETAP simulation is used to validate the calculation results. The observed generator is turned on and others are turned off. Rated load is increased gradually until reached a state where if the loading value is raised again the load flow process becomes divergent. The generating value that is obtained before the load flow process divergent is the maximum limit of the generation which is a steady state stability limit of the generator.

The calculation results of $\mathrm{P}_{\max }$ which is a steady state stability limit of each generator unit compared with result of ETAP simulation can be seen in Table 7. 
Table 5. The load flow result for observed generator is on bus 11 .

\begin{tabular}{|c|c|c|c|c|c|c|c|}
\hline \multicolumn{8}{|c|}{$\begin{array}{c}\text { Power Flow Solution by Newton-Raphson Method } \\
\text { Maximum Power Mismatch }=1.15256 \mathrm{e}-006 \\
\text { No. of Iterations }=3\end{array}$} \\
\hline \multirow[t]{2}{*}{ Bus No. } & \multirow{2}{*}{$\begin{array}{c}\text { Voltage } \\
\text { Mag. }\end{array}$} & \multirow{2}{*}{$\begin{array}{c}\text { Angle } \\
\text { Degree }\end{array}$} & \multicolumn{2}{|c|}{-------Load------ } & \multicolumn{2}{|c|}{-------Generation------ } & \multirow{2}{*}{$\frac{\text { Injected }}{\text { Mvar }}$} \\
\hline & & & MW & Mvar & MW & Mvar & \\
\hline 1 & 0.994 & -0.726 & 7.258 & 4.440 & 0.000 & 0.000 & 0.000 \\
\hline 2 & 0.994 & -0.730 & 33.349 & 22.398 & 0.000 & 0.000 & 0.000 \\
\hline 3 & 0.994 & -0.697 & 36.052 & 25.753 & 0.000 & 0.000 & 0.000 \\
\hline 4 & 0.994 & -0.664 & 25.806 & 17.859 & 0.000 & 0.000 & 0.000 \\
\hline 5 & 0.995 & -0.546 & 33.064 & 21.214 & 0.000 & 0.000 & 0.000 \\
\hline 6 & 0.995 & -0.572 & 36.052 & 17.859 & 0.000 & 0.000 & 0.000 \\
\hline 7 & 0.995 & -0.586 & 30.645 & 16.774 & 0.000 & 0.000 & 0.000 \\
\hline 8 & 0.966 & -0.425 & 0.000 & 0.000 & 0.000 & 0.000 & 0.000 \\
\hline 9 & 0.997 & -0.298 & 39.041 & 31.278 & 0.000 & 0.000 & 0.000 \\
\hline 10 & 0.999 & -0.120 & 32.257 & 24.174 & 0.000 & 0.000 & 0.000 \\
\hline 11 & 1.000 & 0.000 & 0.000 & 0.000 & 536.027 & 211.426 & 0.000 \\
\hline 12 & 0.999 & -0.204 & 27.988 & 34.633 & 0.000 & 0.000 & 0.000 \\
\hline 13 & 0.996 & -0.732 & 18.833 & 13.419 & 0.000 & 0.000 & 0.000 \\
\hline 14 & 0.991 & -1.612 & 15.607 & 35.817 & 0.000 & 0.000 & 0.000 \\
\hline 15 & 0.992 & -1.734 & 0.000 & 0.000 & 0.000 & 0.000 & 0.000 \\
\hline 16 & 0.988 & -2.001 & 40.891 & 31.278 & 0.000 & 0.000 & 0.000 \\
\hline 17 & 0.988 & -2.009 & 9.962 & 8.979 & 0.000 & 0.000 & 0.000 \\
\hline 18 & 0.995 & -0.688 & 0.000 & 0.000 & 0.000 & 0.000 & 0.000 \\
\hline 19 & 0.996 & -1.248 & 13.140 & 1.677 & 0.000 & 0.000 & 0.000 \\
\hline 20 & 0.992 & -1.703 & 24.857 & 24.075 & 0.000 & 0.000 & 0.000 \\
\hline 21 & 0.990 & $\begin{array}{l}-1.963 \\
\end{array}$ & 16.983 & 20.326 & 0.000 & 0.000 & 0.000 \\
\hline 22 & 0.988 & -2.109 & 39.800 & 26.838 & 0.000 & 0.000 & 0.000 \\
\hline 23 & 0.987 & -2.059 & 6.167 & 19.043 & 0.000 & 0.000 & 0.000 \\
\hline 24 & 0.994 & -0.716 & 34.724 & 28.318 & 0.000 & 0.000 & 0.000 \\
\hline 25 & 0.989 & -1.957 & 12.523 & 5.723 & 0.000 & 0.000 & 0.000 \\
\hline & Total & & 535.000 & 431.874 & 536.027 & 211.426 & 0.000 \\
\hline
\end{tabular}

Table 6. Calculation result of $Z_{\text {eq }}$ using losses concept.

\begin{tabular}{|c|l|c|c|}
\hline Bus No. & Generator & $\mathrm{Z}_{\text {eq }}$ & $\mathrm{P}_{\max }$ \\
\hline 1 & Suralaya & $0.000157+\mathrm{j} 0.001752$ & 3574.141 \\
\hline 8 & Muara Tawar & $0.007125+\mathrm{j} 0.068446$ & 2259.334 \\
\hline 10 & Cirata & $0.0001+\mathrm{j} 0.0023$ & 930 \\
\hline 11 & Saguling & $0.0000092792-\mathrm{j} 0.00199184$ & 668.929 \\
\hline 15 & Tanjungjati & $0.012925599-\mathrm{j} 0.21368$ & 2437.331 \\
\hline 17 & Gresik & $0.0014+\mathrm{j} 0.0083$ & 810 \\
\hline 22 & Paiton & $0.0008+\mathrm{j} 0.0044$ & 4786.653 \\
\hline 23 & Grati & $0.01004+\mathrm{j} 0.101927$ & 819.2782 \\
\hline
\end{tabular}


Table 7. Calculation result of $Z_{\text {eq }}$ using losses concept.

\begin{tabular}{|c|l|c|c|}
\hline Bus No. & Generator & $\begin{array}{c}\text { Calculation result using the } \\
\text { proposed method }\end{array}$ & ETAP simulation result \\
\hline 1 & Suralaya & 3574.41 & 3650.827 \\
\hline 8 & Muara Tawar & 2259.334 & 2231.407 \\
\hline 10 & Cirata & 930 & 917.936 \\
\hline 11 & Saguling & 668.929 & 660.898 \\
\hline 15 & Tanjungjati & 2437.331 & 2586.633 \\
\hline 17 & Gresik & 810 & 823.246 \\
\hline 22 & Paiton & 4786.653 & 4746.864 \\
\hline 23 & Grati & 819.2782 & 851.094 \\
\hline
\end{tabular}

\section{Conclusion}

$\mathrm{P}_{\max }$ calculation result obtained by the proposed method is not much different compared with the results obtained by the ETAP simulation. It can be concluded that, the method to change multimachine system into SMIB presented in this paper can be applied and determination of $r_{\text {eq }}$ and $x_{\text {eq }}$ value based on the network losses concept can be done. By using the proposed method, steady state stability limit of each generator in a multimachine system can be determined easily. It will be very useful for guiding the operator in operating their generator safely.

The authors are very grateful to the Power System Simulation Laboratory, Department of Electrical Engineering, Institut Teknologi Sepuluh Nopember (ITS), Surabaya, Indonesia to all facilities provided during this research and the authors are very grateful to Direktur Riset dan Pengabdian Masyarakat, Direktorat Jenderal Penguatan Riset dan Pengembangan through the PDD 2017 Grant Fund.

\section{References}

1. C.Thakur, S. Sahu. Current Trends in Technology and Science, II,VI:330-339 (2013). https://www.ctts.in/assets/upload/8000ctts-415\%20vol-2\%20iss-6.pdf.

2. Ž. Eleschová, A. Beláň. AT\&P journal PLUS2:54-57 (2008). https://www.atpjournal.sk/buxus/docs//casopisy/atp_plus/plus_2008_2/plus54_57.pdf.

3. J. Veleba. Possible steady-state voltage stability analyses of electric power systems [Online] from http://home.zcu.cz/ tesarova/IP/Proceedings/Proc_2011/Files/Veleba.pdf. (2011). [Accessed on 9 July 2017]

4. K. Himaja, T.S. Surendra, S.T. Kalyani. IJERT, 1,7 (2012). https://www.ijert.org/download/1059/steady-state-stability-analysis-of-a-singlemachine-power-system-using-matlab.

5. I.C. Gunadin, M. Abdillah, A.Soeprijanto, O. Penangsang. WSEAS Transactions On Power Systems, 7,3:91-103 (2012). http://repository.unhas.ac.id/handle/123456789/7195

6. J. Lianda. Analisis batas stabilitas steady state dan transient menggunakan metode Radial Equivalent Independent (Rei) Dimo [Stability limit analysis of steady state and transient method using Radial Equivalent Independent (REI) Dimo]. [Thesis]. 
Institut Teknologi Sepuluh Nopember, Surabaya, Indonesia (2011). [in Bahasa Indonesia]. p. 45. http://digilib.its.ac.id/ITS-Undergraduate-3100011042766/15957

7. J. Custer, I. C. Gunadin, O. Penangsang, A. Soeprijanto. Optimisasi operasi sistem tenaga listrik dengan konstrain kapabilitas operasi generator dan kestabilan steady state [Optimization of power system operation using capability constraint of generator operation and steady state stability] [Online] from http://digilib.its.ac.id/public/ITS-paper-20168-Paper.pdf. (2011). [Accesed on 29 March 2014]. [in Bahasa Indonesia]

8. P. Kayal, S. Chanda, C.K. Chanda. International Journal on Electrical Engineering and Informatics, 4,2 (2012). http://www.ijeei.org/docs-43441230750358b3a03515.pdf.

9. G.A. Mahmoud. IET Generation, Transmission \& Distribution, 6,7:612-618. http://ieeexplore.ieee.org/document/6235272/

10. I.C. Gunadin, O. Penangsang, A.Soeprijanto. Influence of load characteristics against voltage collapse phenomena. Proceeding International Conference on Engineering and Meta-Engineering, (Orlando, USA, 2010).

http://www.iiis.org/CDs2010/CD2010IMC/ICEME_2010/index.asp?id=0\&area $=1$ 